\title{
CRIME BORN OF SHAME AND FEAR
}

\author{
RIMA PRASPALIAUSKIENE
}

ABSTRACT The crimes committed by women in most societies account for only about 10 per cent. One would think that women are not inclined to commit crimes, but they dominate in some crimes. Women committed half the murders in nineteenth-century Lithuania. Violent deaths of infants constituted about half of the total cases of violent deaths. Infanticide was the most common type of murder in Lithuania in the nineteenth century.

This study is based on the analysis of court cases of 85 women accused of infanticide. The article analyses the motivation of the accused women, it seeks to give the answer to the question whether these women were cruel. The fact that most of the accused women (88.2 per cent) belonged to the same social layer of unmarried hired farm labourers suggests that infanticide was not an ordinary, accidental crime. It had deep social causes in that society. The women were scared of the reaction of their parents and the entire rural community. Shame and fear of being turned out and becoming an outcast in the community constituted perhaps the main cause of that crime. Poverty was another important cause for committing a crime. Hired farm labourers were afraid of losing jobs. It was especially difficult for a single mother with a child to find employment and to earn a living for herself and her child; quite often she had to go begging. The accused women were familiar with the fate of single mothers. Such a girl had no future in a rural community. Nonetheless, one can think that getting rid of a baby was a primitive form of birth control in the nineteenth century. Therefore these women should not be regarded as cruel. Simply the way that they chose was more acceptable to that social environment in which they lived.

Crimes and criminal behaviour in Lithuania in the nineteenth century are not a new theme and this problem has already been considered by historians. The policing system, the development of punishment, the attitude of the authorities and the public to crimes and criminals in the nineteenth century were discussed by Vladas Sirutavičius. ${ }^{1}$ In her monograph ${ }^{2}$ Dalia Marcinkevičienè drew at-

${ }^{1}$ V. Sirutavičius, Nusikaltimas ir visuomene XIX amžiaus Lietuvoje (Vilnius, 1999).

${ }^{2}$ D. Marcinkevičiene, Vedusiuju visuomene: santuoka ir skyrybos Lietuvoje XIX amžiuje - XX amžiaus pradžioje (Vilnius, 1999). 
tention to the violent behaviour of women towards their spouses and the situation of illegitimate children in traditional Lithuanian society. However, the violent behaviour of women in Lithuania of the nineteenth century is still a new phenomenon, which practically has not been considered by Lithuanian historians so far. The subject of study of the present article is criminal behaviour of women and violent deaths of infants in Lithuania in the nineteenth and the early twentieth century. The study is based on the analysis of criminal actions brought for infanticide. ${ }^{3}$

In many societies only about 10 per cent of crimes used to be committed by women. It would be easy to think that women were not inclined to commit crimes, but they were dominant in some types of crimes. Women committed practically half the number of murders and most often newly born babies fell a victim to them. Violent deaths of babies accounted for about half the cases of violent deaths. Infanticide was usually the most common type of murder in Lithuania in the nineteenth century. Statistics for 18841900 records 696 cases of infanticide in the Kaunas Gubernia, that is, on average 40.9 babies perished in that Gubernia every year ${ }^{4}$. Data for the Vilnius Gubernia are very fragmentary, 106 such cases were recorded in 1896-1900, i.e., on average 21.2 babies perished annually. There is no reliable criminal statistics about this issue covering the whole nineteenth century. However, one can think that the figures recorded, as well as the cases investigated in courts, are only the tip of the iceberg, and the actual scope of these crimes can only be guessed. Why did women try to get rid of their illegitimate babies? Does that mean that they were cruel? Seeking to give an answer to these questions, we have analysed 85 court cases of the women who were accused of infanticide. The existing criminal cases that were brought against women who committed infanticide allow us to draw the conclusion that the violent death of an illegitimate baby surprised nobody in the Lithuanian village in the nineteenth century.

Punishments According to the law, murder was subject to severe punishment. Punishment for infanticide was imposed on the

3 The study was based on the cases of the Supreme Court of Lithuania (Lithuanian Historical State Archive (henceforth LVIA) f. 443, the Department of Criminal Cases of Vilnius Joint Civil and Criminal Court (LVIA), f. 447) and the Vilnius District Court (LVIA, f. 448)

${ }^{4}$ Pamiatnaia knizhka Kovenskoi gubernii, 1884-1900. 
basis of criminal laws of the Code of Laws of the Russian Empire. That Code established the same punishment for premeditated infanticide as for any other type of murder; Article $1999^{5}$ provided for the following punishment for this crime - depriving the individual of all property rights, sending the woman to penal servitude and imposing corporal punishment. However, mitigating circumstances were also provided for in case of infanticide, where ordinary murder was differentiated from the murder of a newly born baby. If the crime was committed against a newly born baby because of a feeling of shame or fear, and the woman had not committed a similar crime before, if she was single and gave birth for the first time, such a woman was subject to the deprivation of all property rights, deportation to Siberia and corporal punishment (Article 2000). ${ }^{6}$ Similar punishments were imposed for leaving the baby without any care, provided that it resulted in its death - corporal punishment, deportation or corrective labour from 3 to 6 years. Women were subject to imprisonment from three months to one year for hiding a stillborn baby due to shame and fear (Article 2009). ${ }^{7}$ By the way, according to the Lithuanian Statute of 1588, the death sentence was imposed for the murder of an illegitimate baby or killing a foetus. ${ }^{8}$ The church punishment of spiritual repentance for living together with a man without marriage was imposed on a woman accused of killing her baby. Spiritual repentance was applied to all women irrespective of the type of punishment that was imposed on them. In 85 cases mentioned above 84 women and one man (a priest) were accused. Different punishments were administered depending on the circumstances of the case - ranging from spiritual repentance in a monastery or an asylum to penal servitude in Siberia. Seven per cent of women were acquitted for lack of evidence, 16 per cent of women had to serve a term of imprisonment, 27 per cent of women were deported to Siberia. Public corporal punishments from 10 to 200 lashes were applied to 30 per cent of the accused. These women were given the lashes in the market places of cities and small towns; spiritual repentance was administered to 20 per cent of the women.

${ }^{5}$ Svod Zakonov Rossiskoi imperii, Ugolovnye zakony, t. 15, 1837, r. X., gl. I, p. 501.

${ }^{6}$ Ibid., p. 501-502.

${ }^{7}$ Ibid., p. 504-505.

8 Статут ВКЛ 1588 года, р. 12, арт. 60 (Минск, 1989), с. 439 
The Accused Women Infanticide in Lithuania was common in rural areas. Practically all the crimes that have been investigated were committed in the countryside. Victims of these crimes without any exception were illegitimate children. Their mothers were Catholics who belonged to the poorest strata of the society - hired farm labourers. They were young, single ( 88.2 per cent) hired farm labourers - peasants, individual farm-hands, as well as those that belonged to the gentry, whom their landlords characterized as good workers. At the time of committing their crime they were twenty years old and were employed by their landlords. Only some of the girls lived in their parents' homes. Married women accounted for 11.8 per cent among the women accused of committing the crime. As a rule they were older and it was not their first birth. They were widows, the wives of army recruits, or women who actually did not live together with their husbands. For example, the peasant Sofija Šalčienè was married for three years but her husband did not live with her. He stayed to live with his parents in Vilnius. The spouses had no children. Neither had they any property. Sofija served in the country and she was made pregnant by her landlord's son. ${ }^{9}$

For many women this was the first crime in their life. Only one accused woman, Marijona Čiotirkute, aged 45, got rid of a baby for the second time. ${ }^{10}$

Sixteen and a half per cent of the accused women had illegitimate children before, but most of them were dead. These women knew what it meant to be a single mother in the society of that time. They could expect help neither from their parents nor their brothers because they themselves were poor and worked as hired labourers. Besides, a large part of young girls had no parents. The peasant Anelè Matuzaitè had a nine-year old illegitimate daughter already. The woman had no permanent place of residence, and had difficulties in finding a job. ${ }^{11}$ Petronèle Rustelytė managed to find a job because her uncle, a reservist, brought up her illegitimate son. ${ }^{12}$

${ }^{9}$ Byla valstietei Sofijai Šalčienei, 1884, LVIA, f. 448, ap. 1, b. 44, f. 7.

${ }^{10}$ Byla Marijonai Čiotirkutei, 1802, LVIA, f. 443, ap. 1, b. 174, f. 1

${ }^{11}$ Byla valstietei Anelei Matuzaitei, 1870, LVIA, f. 447, ap. 1, b. 7655, f. 15.

${ }_{12}$ Byla valstietei Petronèlei Rustelytei, 1846, LVIA, f. 447, ap. 19, b. 1524 , f. 40 . 
Most of these women were born into legal marriages, with only 6 per cent of them being illegitimate daughters of their mothers. These illegitimate mothers themselves had experienced what it meant to be an illegitimate child in their society. Scholastika Drabavičiūte, aged 18, who was accused of killing her baby, was an illegitimate daughter of the noblewoman Tekle Rudzinskaite; her father was also a nobleman. Her mother's sister brought up the girl. Scholastika's mother, Teklè Rudzinskaitè, died in abject poverty and was buried in a nameless grave without the priest's blessing. ${ }^{13}$ The illegitimate peasant Justina Sakenaite gave birth for a second time. Her first daughter died less than a week after she was born. ${ }^{14}$

The fact that most of the accused women belonged to the same social strata of single women allows us to suppose that infanticide was not a simple chance crime. It had deep social causes in that society.

In the Shadow of the Accused Who were partners in the crime? Did they know about the crime? Perhaps their position was one of the causes stimulating women to commit crimes. According to the church canons, a man, like a woman, was regarded as having committed a crime if he lived with a woman without marrying her. If such a man confessed to having had extramarital relations with the accused woman, that is, if he admitted being the baby's father, he was also subject to punishment. The punishment for a man was a spiritual repentance of several weeks or a month. No laws provided for any corporal punishment.

A stereotype of liaison between the lord/landowner and a maid was perpetuated in society. The court cases studied deny in part the basis for such a stereotype. Only as little as 6 per cent of women had extramarital relations with their lords, another 6 per cent were made pregnant by their lord's son or brother. Partners of one fifth (20 per cent) of the women were staying in those environs or they were soldiers who were home on leave. Women made their acquaintance at a dance or in a tavern. The men often lived on the same lord's estate. In 4 per cent of cases fathers of the babies were travelling craftsmen, in 3 per cent of cases the women themselves did not know who made them pregnant. In 15

13 Byla Scholastikai, nesantuokinei bajoraitès Teklès Rudzinskaitès dukrai, 1850, LVIA, f. 447, ap. 19, b. 1000, ff. 7-8.

${ }^{14}$ Byla Justinai Sakenaitei, 1858, LVIA, f. 447, ap. 19, b. 5714, f. 6. 
per cent of the cases studied the women's partners were not mentioned at all. Nevertheless, the hired peasants with whom the women worked constituted the largest part of their sexual partners (46 per cent).

Perhaps one cannot maintain that free sexual relations between the hired farm labourers were the norm of life in those days. On the other hand, hired farm labourers had least possibilities to get married. Therefore it is quite natural that instincts influenced their behaviour. Partners tried to conceal their premarital sexual relations so the surrounding people could only guess how far these relations had gone. Quite often poor girls believed promises to marry them. Since it was not so seldom that hired farm labourers changed their lords, the relations between the partners broke off in a short time. The women often did not even let their partners know that they were pregnant. However, many women who let their partners know about their pregnancy would only be given advice on how to get rid of the unwanted baby. Their advice usually was to conceal or terminate the pregnancy. Actually this behaviour by far could be treated as complicity with the woman in committing a crime. However, their guilt could not be proved. It goes without saying that all the intimate details were discussed between the partners tête-àtête, without the presence of any witnesses, hence the women had no evidence to confirm their statements. Sofija Šalčienè, who wanted to tell her mother and father about her pregnancy, was persuaded by her lord's son, Antanas, to keep silent because he had decided to hide the baby. ${ }^{15}$ When the peasant Elena Gobyte told the hired farm labourer Anupras Bileišis that she was expecting a baby, Bileišis advised her to get rid of the baby during birth. Anupras himself changed his lord and Elena saw no more of him. ${ }^{16}$ The peasant Jadvyga Podgalskaite lived with the hired farm labourer Jonas Podulis as husband and wife for a few months only. Upon learning that he was going to be a father, the husband advised her to get rid of the baby if the latter was born. ${ }^{17}$ The peasant Teodora Kackelaite’'s partner nobleman Pawel Onichimowski made her take 'some black powder' regularly. It made Teodora feel terrible, but

15 Byla valstietei Sofijai Šalčienei, 1884, LVIA, f. 448, ap. 1, b. 44, f. 7.

${ }^{16}$ Byla valstietei Elenai Gobytei, 1908, LVIA, f. 448, ap. 1, b. 27402, ff. 5, 10.

${ }^{17}$ Byla valstietei Jadvygai Podgalskaitei, 1907, LVIA, f. 448, ap. 1, b. 27388 , f. 23 . 
it did not help her terminate her pregnancy. ${ }^{18}$ The unwanted baby would have brought about unnecessary changes in the life of both partners.

When the extramarital relations of the former partners came to light, in most cases men used to deny their guilt. If conflicting evidence were presented, confrontations would be organised. The father of the baby killed by Apolonija Gilkevičiūte was her lord, the nobleman Tadas Radzevičius. During confrontation Apolonija asserted 'with tears in her eyes and standing on her knees' that she was made pregnant by none other than him. Tadas Radzevičius blushed and got confused in his explanations, but he kept asserting all the same that he knew and saw nothing. ${ }^{19}$ As in this case, confrontation seldom changed anything. As a rule, both parties firmly adhered to their positions. Quite often there were cases when men themselves accused a woman of slander and profligacy and maintained that the woman had had several partners, so he could not acknowledge paternity. Those who admitted having had relations with the accused woman maintained that they knew nothing about her pregnancy.

In several cases the women claimed to have been raped. However, they told nobody about the experienced sexual violence and concealed their pregnancy. Pranciška Cikšienè said that a stranger in a tavern had raped her, but she was deeply ashamed of what had happened, and so she told nobody about the rape and her pregnancy. ${ }^{20}$ Two drunken men raped a blind beggar, Kotryna Karačiūtè on the road. The woman told nobody about the incident either. ${ }^{21}$ Kristina Rutkauskaite said that a shoemaker who had been working for the same landlord raped her. The woman did not complain to the landlord about the shoemaker's behaviour. In the court the craftsman denied having had any relations with Rutkauskaite. ${ }^{22}$ There might have been more cases of rape. Not only in Lithuania but also in Western Europe women seldom reported sexual vio-

${ }^{18}$ Byla valstietei Teodorai Kackelaitei, 1862, LVIA, f. 447, ap. 19, b. 9240, f. 5.

${ }^{19}$ Byla valstietei Apolonijai Gilkevičiūtei, 1851, LVIA, f. 447, ap. 19, b. 3982 , ff. $31-32$.

${ }^{20}$ Byla valstietei Pranciškai Cikšienei, 1855, LVIA, f. 447, ap. 19, b. 4144, f. 2 .

${ }^{21}$ Byla valstietei Kotrynai Karačiūtei, 1849, LVIA, f. 447, ap. 19, b. 3841 , f. 28 .

${ }^{22}$ Byla valstietei Kristinai Rutkauskaitei, 1850, LVIA, f. 456, ap. 2, b. 918 , ff. 16,18 . 
lence, as much as 95 per cent of cases of sexual violence were suppressed. ${ }^{23}$

In only one case was a more severe punishment imposed on a man than on his partner. That case is worth discussing because it was really unusual since the accused was a priest. The priest made up his mind to take this step to protect his reputation. The fifty-year old priest Jonas Račinskis was deprived of gentry status and deported to Siberia for hard labour. His partner, Marijona Skripinskaite, was also deported. Račinskis had maintained extramarital relations with the twenty-five year old peasant Marijona who served him. Some time later his maid Marijona told him that she was pregnant. The priest forbade the girl to tell anybody about it. He hoped it would be possible to terminate her pregnancy and made the women drink water with mercury regularly. The woman's brother noticed her pregnancy. The priest kept the girl under lock and key and allowed nobody to visit her. He tried to persuade her that it was necessary to 'lose' the baby. Jonas Račinskas was insistent; he himself delivered the baby and suffocated it. He told Marijona that she had given birth to a stillborn child. The priest put the infant into a barrel and hid it in a lumber-room. ${ }^{24}$ The priest hoped he would find a suitable moment to bury the body. Fr. Jonas Račinskis behaved in the way many accused women did. In that case the priest was eager to protect his reputation and have the possibility to live quietly in society. On the other hand, the case specified shows that attempts to get rid of an illegitimate baby and thus avoid becoming a social outcast were deeply rooted in the public awareness not only in the lower strata of society.

Open Secrets Women tried to conceal their pregnancy. They told nobody about it. Sometimes they concealed this fact even from the father of a child. They tried to get over their trouble and solve the problem on their own. The future life of these women depended on how they managed to do that. Judging from the evidence presented by the accused women in courts, it becomes clear that the women themselves often did not understand what had happened to them. It was only when the time of delivery came nearer that they

${ }^{23}$ O. Hufton, The Prospect Before Her. A history of Women in Western Europe, Vol. I, 1500-1800 (Glasgow, 1995), p. 264.

${ }^{24}$ Byla dèl bajorystès teisių atemimo iš dvasininko bei ištrèmimo i Sibirą kunigo Jono Račinsko ir valstietès Skripinskaitès, 1839, LVIA, f. 381, ap. 7, b. 1683, f. $2-3$. 
understood their position and the changes that took place in their bodies. Pregnancy did not interfere with the routine rhythm of their life. Ieva Kaminskaite suffocated her newly born baby and hid it in a heap of manure. She gave birth to a baby in a barn, all by herself. She tried to conceal her pregnancy, ate and drank very little and her belly was always tightly pressed. ${ }^{25}$ When the peasant Elena Gobyte started to appear pregnant to those around her, people asked her if she was pregnant. She always denied that by repeating the following: 'I have been plump since I was a girl' ${ }^{26}$ Ona Važinskaitè worked hard in the fields without complaining to anyone or telling anybody about her pregnancy. ${ }^{27}$ Scholastika Drabavičiūtè who became pregnant by a travelling Latvian craftsman, Eduardas Vitmanis, tried especially hard to lift all kinds of heavy things. ${ }^{28}$ The hired farm labourer Domicele Gruzdaite was ashamed to tell anyone about her relations with soldier Karolis and about her pregnancy. ${ }^{29}$

Looking for an answer to the question why most of the accused women concealed their pregnancy, first of all, one should ask with whom they could share their 'trouble' and who could help them. Their lords were interested in having an able worker, otherwise the girl would have lost her work. If the girls had told their secret to their friends the entire surrounding area would have learned about it in no time and the girl would have been held up to shame. Parents, brothers and sisters could be their only consolation. Some mothers or brothers tried to help the women by giving them various herbal alcoholic solutions to terminate pregnancy or to cause the baby to be stillborn. However, many of the accused women had neither parents nor relatives. Those who had parents seldom turned to them for help. Many of them, like Jadvyga Podgalskaite, carefully concealed pregnancy even from their parents because they were afraid of being turned out of their parents' house and were afraid to be sneered at by their neighbours. ${ }^{30}$ They forecasted the behaviour of their parents on the basis of experience of other

${ }^{25}$ Byla valstietei Ievai Kaminskaitei, 1844, LVIA, f. 447, ap. 19, b. 1014 , ff. $27-28$.

${ }^{26}$ Byla valstietei Elenai Gobytei, 1908, LVIA, f. 448, ap. 1, b. 27402, ff. 4-6.

${ }^{27}$ Byla valstietei Onai Važinskaitei, 1843, LVIA, f. 447, ap. 19, b. 177, f. 18.

${ }_{28}$ Byla Scholastikai, nesantuokinei bajoraitès Teklès Rudzinskaitès dukrai, 1850, LVIA, f. 447, ap. 19, b. 1000, ff. 7-8.

${ }^{29}$ Byla valstietei Domicelei Gruzdaitei, 1870 , LVIA, f. 447, ap. 1, b. 5838 , f. 8 .

${ }^{30}$ Byla valstietei Jadvygai Podgalskaitei, 1907, LVIA, f. 448, ap. 1, b. 27388 , f. 23 . 
women. The girl was considered to have disgraced not only herself but also her whole family and even her relatives. Such a girl was really threatened with being turned out of her parents' house and losing her dowry, as well as the chance of getting married.

Therefore it was quite natural for them to keep their own counsel. They justified their indisposition by backaches, headaches or toothaches. When the time to give birth came they tried to avoid the presence of other people around.

The girls gave birth to their babies on their own, hidden in a granary, the attic, the fields and forests or on the road. Giving birth to a child could not destroy the rhythm of everyday life either. Having given birth to a baby and having got rid of it in one or another way, that is, having murdered and hidden it, the women returned to work immediately. Most of the women further kept their secret.

Nevertheless, lords and other hired farm labourers or neighbours noticed the changes in the body of a woman or any other marks, for example, bloodstained clothes, traces of blood in cowsheds or some other places. The labourers who worked together with the girl had suspected that she was pregnant, but they mentioned it neither to the lords nor the girl herself. In this way the undesirable pregnancy was kind of an open secret, and silence could be regarded as tolerance of the girl's implied behaviour. It was only after the rumours started to circulate in the area that the elder or raktvaitis would begin to investigate their validity and the crime would come to light.

The Crime and its Disclosure In most cases the crime would come to light by pure chance only, that is, if traces of delivery or the body of a baby were found. Since many girls used to give birth on their employer's estate, the latter reported the crime committed to the police, the elder or the priest. It was probable that often the lords or parents reported those crimes to nobody. These cases could be similar to that of peasant Joana Valaite who became pregnant by her lord's son Mykolas, gave birth to a baby, killed and hid it. Her mistress found the body of the baby when Joana was about to get married. Joana begged her mistress to keep the secret. The mistress turned her out of her house with the dead body of the baby, but she told only her father about it. The girl buried the body secretly in her parents' homestead under a cross. In that case the girl's parents and her mistress kept the secret. The secret was 
revealed later, when Joana was already married. ${ }^{31}$ If the crime was disclosed after a long period of time had passed, usually it was difficult to determine the cause of death of the baby and the accused would get away with spiritual repentance only for living with a man without marrying him or would remain unpunished altogether, as in the case of Joana Valaite. One can only guess how many cases remained undisclosed and did not come to court.

When the estate owners or the police officers started to make clear the circumstances of the crime the accused women denied everything. Practically they presented the same version - the baby was stillborn, therefore it was buried in secrecy. After examining the body a physician or a pharmacists determined the cause of its death. They also examined the accused herself to make sure that she had given birth a short time ago. Forensic pathology and the evidence provided by the accused women testified to a cruel treatment of babies. However, the answer to the question whether these women could be regarded as cruel or merciless can be found only in the analysis of the causes of the crime. During interrogation the accused themselves explained why they had done what they did. The fact that the greater majority of girls and women concealed their pregnancy can be some kind of proof that the crimes were premeditated and planned very well in advance. On the other hand, many accused women did everything to make the baby stillborn.

Causes of the Crime A new-born child was neither needed nor welcome in any way. There could have been three ways of solving that problem: abortion, abandoning the baby or its death. Termination of pregnancy was not common in the society of those days, which is attested to by a small number of court cases. That is, it was only at the end of the nineteenth and the beginning of the twentieth century that criminal abortion became an everyday phenomenon. There were no possibilities to leave the baby on the doorstep of somebody's house. Foundlings were usually an urban phenomenon. City women could give birth at health care institutions assisted by midwives. An unwelcome baby could be left in orphanages established at monasteries or the houses of some city-dwellers, etc. There were no shelters or orphanages intended for babies or single mothers in rural parishes. Foundlings were a common

${ }^{31}$ Byla valstietei Joanai Valaitei, 1801, LVIA, f. 443, ap. 1, b. 36, f. 1. 
phenomenon in nineteenth-century Vilnius, as a large number of court cases related to abandoned children confirm. The death of unwelcome babies was the most acceptable way out for the rural society and this opinion is evidenced by the detailed analysis of the causes of the crime.

'I Did That out of Shame and Fear,' maintained more than one accused woman. 'Four days before delivery I decided that I would give birth in the field and get rid of the baby. I told nobody about my plan, nobody taught me how to behave, I did that out of shame and I wanted to evade derision of the strangers', ${ }^{32}$ said Domicele Gruzdaite, who already had an illegitimate son. Having drowned her baby the peasant Marijona Kregždaite said she 'had liberated herself from disgrace'. 33 'When I was with the baby I never cherished hopes that it should live because people would have scoffed at me and put me to shame', claimed Anele Matusevičiūte. ${ }^{34}$ The reaction of the estate-owners, parents and the entire rural community frightened these women. Shame and fear of being turned out of the house or being ousted from the community constituted perhaps the main cause of the crime.

Alongside fear and shame there was another cause for committing a crime - and that was poverty. 'About a month before giving birth I understood that with a baby I would have no possibility at all of being employed and earning a living $<\ldots .>$ I started thinking about it more often and finally I decided to smother the baby after giving birth to it if I only had a possibility to do that, tell nobody about it and go on serving my master,' confessed Doroteja Kavoliūte. ${ }^{35}$ The peasant Justina Sakenaitè said that at first she did not plan to get rid of her baby. However, not knowing what to do with it, she committed the crime out of shame and fear that nobody would employ her. ${ }^{36}$ 'With the birth of my baby I would have lost everything and I am poor as it is. With a baby I would have never been able to earn enough to feed the baby and myself. I had nobody I could expect help from, I have only a brother, however,

32 Byla valstietei Domicelei Gruzdaitei, 1801, LVIA, f. 447, ap. 1, b. 36, f. 1.

${ }^{33}$ Byla valstietei Marijonai Kregždaitei, 1865, LVIA, f. 447, ap. 1, b. 4384, f. 3.

${ }^{34}$ Byla vienkiemininkei Anelei Matusevičiūtei, 1837, LVIA, f. 456, ap. 2, b. 40, f. 15.

${ }^{35}$ Byla valstietei Dorotejai Kavoliūtei, 1869, LVIA, f. 447, ap. 1, b. 6123, f. 1.

${ }^{36}$ Byla valstietei Justinai Sakenaitei, 1858, LVIA, f. 447, ap. 19, b. 5714 , f. 6 . 
his family lives very poorly' ${ }^{37}$ is how the peasant Cecilija Bartuševičiūte justified her action. The hired farm labourer was afraid to be left without a job. It was impossible for a single mother with a baby to find a job and earn a living for herself and her baby, thus quite often she had to go begging. The accused women knew very well the fate of single mothers such as peasant Agota Makrickaite. Nobody employed her when she had a baby and she repeatedly asked her masters to employ her. The only answer they gave was that they did not want to see her with her baby and that they were not going to feed two mouths. Besides they said that Agota would look after her baby rather than work. There was only one way out for that peasant - to go begging together with her child. ${ }^{38}$

The opinion of peasants and their position played a considerable role in the decision that the women took. Their opinions show what they thought of the women who had committed crimes and whether those women were rough or notorious for their promiscuous behaviour. By the way, the opinion of the surrounding people was of great importance to the court too because the severity of the punishment partly depended on it. Only several women were characterized by the peasants in a negative way. One of them was Konstancija Dikevičiūte, who was notorious for her free behaviour, the peasants often saw her spending time with passing soldiers. ${ }^{39}$ Women who had had illegitimate children already, as well as those who often attended 'dances' were characterized by the peasants in a less positive way too. Nevertheless, most of the women were characterized in the positive both by their masters and the rural population. Before committing their crime they had been industrious and had behaved very well. The words of the peasants show that they understood why the women had behaved in that way and in their evidence they did not moralise those women. The peasant Stanislovas Kildenis characterised the accused, Doroteja Kaviliūte, as follows: 'she lived in our village and earned a living for herself because she had neither parents nor relatives. She is honest and has never been

${ }^{37}$ Byla valstietei Cecilijai Bartuševičiūtei, 1876, LVIA, f. 669, ap. 4, b. 1533 , f. 23 .

${ }^{38}$ Byla valstietei Agotai Makrickaitei, 1853, LVIA, f. 447, ap. 19, b. 4958, f. 11 .

${ }^{39}$ Byla valstietei Konstancijai Dilkevičiūtei, 1853, LVIA, f. 447, ap. 19, b. 4958, f. 11. 
suspected of thefts or any other crimes $\langle\ldots\rangle$ she did that out of shame and poverty'. ${ }^{40}$ Other inhabitants of the Vilkantai village spoke in the same way. Six inhabitants of Punaroniai village interviewed maintained that the accused, Ona Važinskaite, was respectable, she was one of those girls who were noted for their good behaviour and had never been seen doing anything bad or wrong. ${ }^{41}$ As can be seen, most girls were good labourers and were not noted for their promiscuous behaviour. The crime they committed was not the result of their improper lifestyle. Quite often the action of the girls was absolutely unexpected for the people surrounding them. They had to choose one of the two realistic alternatives - to be a single mother or commit a crime. From the point of view of the Church they were guilty in both cases. Though the law did not regard giving birth and bringing up an illegitimate child as a crime, in reality single mothers were looked upon in society in the same way as women who committed a crime, that is, who murdered their baby, or even worse. Punishing girls who gave birth to a child was ritualized and contained some elements of derision, which had to be endured. Single mothers used to be the object of public sneering. On Sundays the girls had to lie prostrate in the church. They were also made go round the church on their knees, followed by a beggar with a stick and the women, hired men and shepherds jeered at them. This was not enough, many of such girls were avoided on the road. Nobody asked them to dance and masters refused to employ them. ${ }^{42}$ In some places there were pillories next to churches to which the sinners were tied; they had to bow to the passers-by. Such girls were not allowed to enter the church and could only stand at the church door. ${ }^{43}$

The peasant Agnieška Buržinskaitė killed her baby not only because she felt ashamed but because she expected to get married. ${ }^{44}$ However, a single mother and the girl who had given birth

${ }^{40}$ Byla valstietei Dorotejai Kavoliūtei, 1869, LVIA, f. 447, ap. 1, b. 6123, f. 17.

${ }^{41}$ Byla valstietei Onai Važinskaitei, 1843, LVIA, f. 447, ap. 19, b. 177, f. 20.

42 J. Miscevičius, 'Apie dorovinių nusižengimų būdus Žemaičiuose', Gimtasis kraštas, 1938, Nr. 3-4, pp. 413-414.

${ }^{43}$ P. Bugailiškis, 'Šis-tas apie mūsų dorovinių prasižengimų baudžiamuosius papročius', Gimtasis kraštas, 1938, Nr. 1-2, pp. 265-266.

${ }^{44}$ Byla valstietei Agnieškai Buržinskaitei, 1843, LVIA, f. 447, ap. 19, b. 5367, f. 2 . 
to a baby, if she failed to conceal it, seldom got married. She was regarded as having lost her honour, that is, as a degraded woman, she was called a 'debauchee', 'a libertine' and 'profligate'. Such women had no future in the rural society. Such an attitude is reflected in the prayer book too. Women of sin were doomed to 'horrible diseases, beggary, unexpected and early death'. 'It led many women to weariness, and distorted many a life'. ${ }^{45}$ On the whole, only the family lifestyle was valued in nineteenth-century communities. Single women, like single men, were not regarded as equal members of the society. ${ }^{46}$

It was not only the fate of a single mother but also that of her bastard child, that was unenviable in the nineteenth century. Bastards and their mothers were not tolerated in the Lithuanian family. ${ }^{47}$ A child of an unmarried girl was subject to the same contempt as his mother. People in the village who felt pity for such a girl and her child were few in number ${ }^{48}$. The village could not bear a girl with a child. For a woman and her child it meant condemnation and sneer from the side of the community and the Church, as well as life in poverty. Courts also reflected the opinion of the community. They did not take the side of single mothers either. These mothers could bring an action against their child's father demanding maintenance for the child. The number of women who chose this way and what the court decisions were are unknown. However, according to historians, peasant courts rarely satisfied the woman's claim. It is paradoxical that by rejecting women's claims it was sought to put a stop to profligacy. The opinion prevailed that girls were seduced of their own free will. In the society of those days this was considered a self-evident truth. Besides it was said that 'a well-behaved daughter of good parents, even if she has been seduced due to unfortunate attractions, made drunk, etc., does not only not complain but even tries to conceal all that from strangers. If she, disregarding her honour, complains, openly declaring

45 Wadowas i dangu ir meditacijos diel penkiu dienu rekolekciju. Parasze kunigas Jeronimas Raczkauskis, Inspektorius Warniu Seminarijes, Wilniuje, 1861, pp. 106-107.

${ }^{46}$ Marcinkevičienè, Vedusiuju visuomenè, pp. 28-29.

${ }^{47}$ Ibid.

48 A. Bylaitè, 'Kapsų bendravimo etiketas', Darbai ir dienos, 1999, 11(20), p. 211. 
that she was disgraced, it means that she is shameless' ${ }^{49}$ Hence, if a girl feels no shame to complain, nobody could prevent her from going astray, it was she who allowed herself to be seduced. Such judicial practice deprived a single mother of a civilized alternative and pushed her indirectly towards committing a crime.

In conclusion, we can say that women who killed their babies should be assessed from two points of view. On the one hand, they really committed a crime, but on the other hand, they were also victims of this crime of disgrace and fear. The girl who made up her mind to give birth to a baby and keep it was doomed to the same fate as, or an even a more cruel one than the girl who committed a crime. The girl who was determined to commit a crime still had some chance to conceal it. The number of girls who saved their reputation in such a way remains a secret.

Translated by Aldona Matulyte

\section{Author Details}

Rima Praspaliauskienè graduated from the Vilnius Pedagogical University and did her doctoral studies at the Lithuanian Institute of History and Vytautas Magnus University. Her field of interest is the social history of women in the nineteenth and twentieth centuries.

Address: Department of 19th-Century History, Lietuvos istorijos institutas, Kražių 5, LT-2001 Vilnius, Lithuania

Email: rimaprasp@takas.lt

\section{GĖDOS IR BAIMĖS NUSIKALTIMAS}

Santrauka

\section{RIMA PRASPALIAUSKIENE}

Daugelyje visuomeniu moterys ivvykdydavo tik apie $10 \%$ nusikaltimu. Būtu iprasta manyti, kad moterys nebuvo linkusios nusikalsti, tačiau kai kuriuose nusikaltimuose jos dominavo. XIX a. Lietuvoje praktiškai puse nužudymu įvykdydavo moterys, o jų aukomis neretai tapdavo ką tik gimę vaikai. Smurtinès kūdikių mirtys sudarè apie pusę visų smurtinių mirčiu atvejų. Kūdikio nužudymas buvo dažniausiai pasitaikantis žmogžudystès tipas XIX a. Lietuvoje.

49 Б. Я. Фридман, Юридические возрения и случаи крестьян Севернозападного края преимущественно Ковенской губернии (Vilnius, 1890), c. $37-38$. 
Tyrimas grindžiamas 85 moterų, kaltinamų kūdikių nužudymu, teismų bylų analize. Straipsnyje analizuojama kaltinamujų motyvacija, siekiama atsakyti i klausimą ar moterys buvo žiaurios? Tai, kad dauguma kaltinamuju $(88,2 \%)$ priklauso vienam netekèjusių samdinių socialiniam sluoksniui, leidžia manyti, kad kūdikio nužudymas nebuvo paprastas, atsitiktinis nusikaltimas, jis turejo gilias socialines priežastis toje visuomeneje. Moteris baugino šeimininkų, tèvų ir visos kaimo bendruomenès reakcija. Gẻda ir baimè būti išvarytai, atstumtai bendruomenès buvo bene pagrindinè šio nusikaltimo priežastis. Kita svarbi priežastis nusikalsti - skurdas. Samdinès bijojo likti be darbo. Vienišai motinai su vaiku buvo be galo sunku susirasti tarnybą, išlaikyti save ir vaika, tad neretai tekdavo elgetauti. Kaltinamosios puikiai žinojo ir buvo susidūrusios su vienišų motinų likimais. Kaimo bendruomenejje tokia mergina neturejjo ateities. Visgi galima manyti, kad XIX a. netekèjusioms moterims atsikratymas nepageidaujamu vaiku buvo ir primytivi gimstamumo kontrolès forma. Todèl šias moteris būtų sunku pavadinti žiauriomis, tiesiog toks kelias, koki jos pasirinko, buvo artimas tai socialinei aplinkai, kurioje jos gyveno.

Received 26 July 2001 